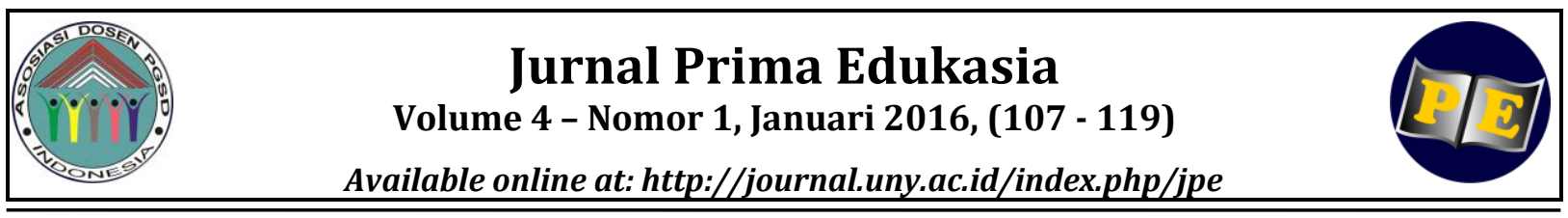

\title{
PENGARUH METODE PBL DAN METODE EXPOSITORY TERHADAP HASIL BELAJAR MATEMATIKA PADA SISWA KELAS V
}

\author{
Noviarda Yastika ${ }^{1)}$, Haryanto ${ }^{2)}$ \\ ${ }^{1}$ SD Negeri 1 Bantul, Jl. Gatot Subroto, Mandingan, Ringinharjo, Bantul, 55712 Indonesia \\ ${ }^{2}$ Program Studi Kurikulum dan Teknologi Pendidikan, Universitas Negeri Yogyakarta. Jalan Colombo \\ No.1 Karangmalang, Yogyakarta 55281, Indonesia \\ Email: ${ }^{1}$ noviarda@yahoo.co.id, ${ }^{2}$ haryanto_tp@uny.ac.id
}

\begin{abstract}
Abstrak
Penelitian ini bertujuan untuk mengetahui perbedaan rata-rata hasil belajar pada siswa yang mendapat pembelajaran menggunakan metode Project-based learning dan siswa yang yang mendapat pembelajaran menggunakan metode expository pada siswa kelas V SD di Gugus I Kecamatan Bantul. Penelitian menggunakan metode eksperimen semu. Desain yang digunakan kelompok kontrol pratespascates berpasangan. Penelitian dilakukan pada siswa kelas V SD di Gugus I Kecamatan Bantul. Pengumpulan data menggunakan angket hasil belajar afektif, tes hasil belajar kognitif, dan lembar observasi hasil belajar psikomotor. Uji validitas menggunakan expert judgement dan uji korelasi product moment. Uji reabilitas menggunakan cronbach alpha. Teknik analisis data yang digunakan adalah teknik analisis data multivariat MANOVA dengan taraf signifikansi 0,05. Hasil penelitian menunjukkan adanya perbedaan hasil belajar yang signifikan antara siswa yang mendapat pembelajaran menggunakan metode Project-based learning dengan siswa yang mendapat pembelajaran menggunakan metode expository. Terdapat perbedaan signifikan pada taraf signifikansi $(0,000)$ kurang dari $\alpha(0,05)$. Hasil belajar baik hasil belajar afektif, hasil belajar kognitif, dan hasil belajar psikomotor dari kelas eksperimen mempunyai rata-rata yang lebih besar daripada kelas kontrol.
\end{abstract}

Kata kunci: Project-based learning, expository, hasil belajar

\section{THE EFFECTS OF PBL METHOD AND EXPOSITORY METHOD ON MATHEMATICS LEARNING OUTCOMES IN CLASS V}

\begin{abstract}
This study aims to find out the average difference in the learning outcomes of students who received learning using Project-based learning method and students who received learning using expository method in the fifth grade students elementary school in the first group of sub-districts of Bantul. The study used a quasi-experiment method. The design was a matching pretest-postest control group design. The study was conducted at the fifth grade students in the first group of Bantul districts. The data were colected using questionnaires of affective learning outcomes, a cognitive achievement test, and observation sheets of psychomotor learning outcomes. The validity test used was expert judgment and product moment correlation test. Reliability test used Cronbach Alpha. The data were analyzed using technique of multivariate data analysis MANOVA with a significance level of 0.05.The research shows significant differences in learning outcomes between students who receive learning using Project-based learning method and those getting learning using expository method. There are significant differences in the Sig. (0.000) less than $\alpha(0.05)$. Affective learning outcomes, cognitive learning outcomes, and psychomotor learning outcomes of the experimental class have an average bigger than that of the control class.
\end{abstract}

Keywords: Project-based learning, expository, learning outcomes

How to Cite: Yastika, N., \& Haryanto, H. (2016). Pengaruh metode PBL dan metode expository terhadap hasil belajar matematika pada siswa kelas V. Jurnal Prima Edukasia, 4(1), 107 - 119. Retrieved from http://journal.uny.ac.id/index.php/jpe/article/view/7716 


\section{Jurnal Prima Edukasia, 4 (1), Januari 2016 - 108}

Noviarda Yastika, Haryanto

\section{Pendahuluan}

Pendidikan di Sekolah Dasar (SD) mempunyai peranan yang penting dalam mendukung proses pendidikan di tingkat yang lebih tinggi. Pendidikan di SD sebagai dasar bagi anak untuk melanjutkan pendidikan ke tingkat menengah dan tinggi. Pemerintah telah memberlakukan kurikulum baru yang disebut dengan Kurikulum 2013 yang pelaksanaannya dimulai tahun pelajaran 2013/2014. Implementasi kurikulum tersebut diatur dalam Permendikbud Nomor 81 A Tahun 2013. Berdasarkan kurikulum 2013 pelaksanaan pembelajaran dilakukan melalui pendekatan saintifik secara tematik terpadu. Penerapan pembelajaran tematik terpadu dengan pendekatan saintifik tersebut membawa implikasi perubahan dalam pembelajaran di SD. Perubahan yang terjadi salah satunya adalah dalam hal metode pembelajaran yang dilakukan guru di kelas. Menurut Hosnan (2014, p.ix) pembelajaran berbasis kurikulum 2013 mempunyai prinsip-prinsip: (1) pembelajaran berpusat pada siswa, (2) pembelajaran mengembangkan kreativitas siswa, (3) guru menciptakan kondisi menyenangkan dan menantang, (4) pembelajaran bermuatan nilai, etika, estetika, logika, dan kinestetika, dan (5) menyediakan pengalaman belajar yang beragam melalui penerapan berbagai strategi dan metode pembelajaran yang menyenangkan, kontekstual, efektif, efisien, dan bermakna. Siswa mendapatkan pengalaman belajar seperti: (1) menemukan sendiri dan mentransformasikan informasi kompleks, (2) mengecek informasi baru dengan yang sudah ada di dalam ingatannya, (3) melakukan pengembangan menjadi informasi atau kemampuan yang sesuai dengan lingkungan dan zaman tempat dan waktu ia hidup.

Dengan pembelajaran yang menggunakan pendekatan saintifik maka guru dapat meningkatkan kemampuan berpikir siswa seperti kemampuan siswa berfikir nalar untuk menjawab pertanyaan yang lebih rumit dan atau memecahkan suatu kasus masalah yang lebih rumit daripada kemampuan berpikir tingkat rendah yang hanya dapat menjawab pertanyaan sederhana (Kemendikbud, 2013, p.5). Pembelajaran saintifik dirancang sedemikian rupa sehingga siswa secara aktif membangun konsep melalui tahapan-tahapan mengamati, merumuskan masalah, mengajukan hipotesis, mengumpulkan data, menganalisis data, menarik kesimpulan dan mengkomunikasikannya. Penerapan kurikulum 2013 dimaksudkan untuk mengganti kurikulum sebelumnya yaitu kurikulum tingkat satuan pendidikan 2006 (KTSP 2006). Kurikulum 2013 merupakan penyempurnaan dan perubahan bagi KTSP 2006 dalam hal standar isi, standar proses, standar penilaian, dan standar kompetensi lulusan. Dalam sosialisasi dan pelatihan kurikulum 2013 dijelaskan bahwa KTSP 2006 mempunyai karakteristik pembelajaran beberapa diantaranya adalah bersifat berpusat pada guru, satu arah, siswa pasif, abstrak, dan individual. Perubahan pada kurikulum 2013 adalah pembelajaran berpusat pada siswa, interaktif, siswa aktif menyelidiki, konteks dunia nyata, dan berbasis tim. Pada muatan pelajaran juga terdapat perubahan dari implementasi kurikulum 2013 dari kurikulum sebelumnya.

Sekolah Dasar (SD) di Wilayah Gugus I Kecamatan Bantul melaksanakan Kurikulum 2013 pada tahun pelajaran 2014/2015. Dari hasil wawancara terhadap guru kelas $\mathrm{V}$ yang telah mengajar menggunakan kurikulum 2013 di salah satu SD dapat disimpulkan dalam mengajar kurikulum 2013 dengan pendekatan saintifik guru belum menggunakan metode yang mendukung pendekatan saintifik. Pelaksanaan kurikulum 2013 terbatas pada pendekatan terpadu dalam materinya saja. Guru mengajar dengan metode ceramah (expository) dan pemberian tugas, terutama pada kompetensi muatan matematika pembelajaran masih berpusat pada guru dan bersifat abstrak. Implementasi pembelajaran kurikulum 2013 belum dilakukan dengan baik dan masih banyak menerapkan standar kurikulum sebelumnya.

Keterampilan alamiah yaitu mengamati, menanya, mengumpulkan informasi, mengasosiasi, dan mengkomunikasikan yang diharapkan pada pendekatan saintifik belum diterapkan secara maksimal. Penelitian ini memilih pengaruh dari metode Project-based learning karena metode ini mempunyai langkah-langkah dan mendorong siswa mendapatkan pengalaman belajar sesuai tahapan-tahapan pada pendekatan saintifik. Project-based learning adalah metode pembelajaran yang menggunakan proyek untuk mencapai tujuan pembelajaran. Pendekatan yang digunakan adalah student centered (berpusat pada siswa). Penggunaan metode Pembelajaran Berbasis Proyek (Project-based learning) sesuai dengan pendekatan saintifik dalam Kurikulum 2013. Hal ini terutama pada proses belajar dalam Project-based learning berpusat pada siswa. Melihat kenyataan di atas maka diperlukan sebuah data empiris yang 
menjelaskan mengenai pembelajaran dengan karakteristik kurikulum 2013 mempunyai hasil belajar yang lebih baik jika dibandingkan dengan pembelajaran yang dilakukan oleh guru. Dalam penelitian ini menggunakan perbedaan pengaruh metode Project-based learning terhadap hasil belajar dibandingkan dengan pengaruh metode expository terhadap hasil belajar.

Project-based learning sebagai pendekatan pembelajaran yang efektif yang hasilnya adalah meningkatkan keterlibatan siswa dan prestasi siswa (Bender, 2012, p.1). Pembelajaran Project-based learning memberikan pengalaman belajar kepada siswa dengan keterlibatan yang sangat tinggi dalam proses pembelajaran. Siswa menjadi pebelajar yang aktif dan mandiri dalam membangun pengetahuan. Kemudian Yam \& Rossini (2010, p.1) menjelaskan bahwa Project-based learning adalah suatu pendekatan pembelajaran yang berpusat pada siswa (student-centered) digunakan untuk mempromosikan pembelajaran aktif dan mendalam dengan melibatkan siswa dalam menyelidiki masalah dunia nyata dalam lingkungan kolaboratif.

Barell, Baron, Belland, et al. dalam Bender $(2012$, p.1) menjelaskan metode Project-based learning membuat siswa menghadapi permasalahan nyata di dunia dan masalah yang mereka temukan, menentukan bagaimana menyelesaikannya, dan kemudian bekerja secara kolaboratif untuk membuat pemecahan masalah.

Pembelajaran yang berpusat pada siswa dan memberikan pengalaman siswa untuk aktif dan terlibat dalam proses belajar mempunyai pengaruh positif terhadap pencapaian hasil belajar. Hasil belajar adalah kemampuan-kemampuan yang ada pada diri siswa setelah menerima pengalaman dalam proses pembelajaran (Sudjana, 2013, p.22). Hasil belajar berdasarkan pernyataan yang telah ditetapkan atau tujuan pembelajaran yang menunjukkan kondisi siswa setelah mengalami proses pembelajaran. Lebih lanjut Moon (2002, p.56) menjelaskan hasil belajar (learning outcomes) sebagai pernyataan mengenai apa yang siswa diharapkan untuk mengetahui, memahami dan dapat melakukan pada akhir masa belajar dan bagaimana belajar itu yang akan ditunjukkan. Nitko \& Brookhart (2011, p.25) menjelaskan bahwa tujuan pembelajaran disusun dengan skema yang tinggi untuk membuat kategori ke dalam tingkat kesulitan yang berbeda-beda. Secara umum tujuan pembelajaran merupakan salah satu dari tiga ranah, tujuan yang bersifat kompleks mungkin saja melibatkan lebih dari satu ranah. Hal ini menunjukkan bahwa hasil belajar diukur berdasarkan tujuan pembelajaran yang disusun berdasarkan tiga ranah yaitu ranah kognitif fokus pada pengetahuan dan kemampuan yang memerlukan ingatan, berpikir, dan proses penalaran. Ranah afektif fokus pada perasaan, minat, sikap, dispositions, dan status emosi. Ranah psikomotor fokus pada keterampilan gerak dan proses persepsi.

Berdasarkan hasil penelitian Romanov dan Nevgi (2008, p.159) disimpulkan bahwa hasil belajar yang lebih baik berhubungan dengan aktivitas belajar yang tinggi. Siswa belajar dengan sumber belajar yang lebih banyak. Siswa saling berbagi pengalaman dan pengetahuan dengan siswa lain sehingga secara aktif menemukan hubungan antara materi pelajaran dan lingkungan atau situasi kerja nyata. Begitu pula Srinath (2014, p.21) menjelaskan bahwa guru dapat menerapkan strategi belajar aktif untuk mendapatkan hasil belajar yang lebih baik. Pengetahuan guru dalam memberikan ilustrasi yang relevan dan sesuai dengan pengetahuan siswa akan membantu menghubungkan teori dengan aplikasi atau penerapannya. Pelaksanaan pembelajaran dengan menggunakan model pembelajaran kreatif dan produktif juga dapat mengakibatkan peningkatan motivasi dan hasil belajar siswa (Oya \& Budiningsih, 2014, p.125)

Sedangkan pembelajaran yang terpusat pada guru dan kurang melibatkan siswa untuk aktif dalam pembelajaran tidak mempunyai pengaruh terhadap hasil belajar. Seperti hasil penelitian Steven (2015, p.13) disimpulkan bahwa tidak ada perbedaan yang signifikan pada hasil belajar siswa yang mendapat pembelajaran tradisional (tatap muka dengan guru di kelas) dengan siswa yang mendapat pembelajaran secara online. Tidak adanya perbedaan yang signifikan karena keadaan siswa yang sama-sama pasif dan pembelajaran berpusat pada guru.

Contoh metode dengan pendekatan berpusat pada guru adalah metode expository. Metode expository adalah pembelajaran yang berpusat pada guru sebagai pengendali kelas dan imparter pengetahuan. Guru melakukan pekerjaan, dan siswa yang mungkin atau mungkin tidak terlibat dalam pembelajaran tetapi harus menyerap informasi. Kebanyakan aktivitas karakteristik metodologi expository adalah ceramah (Martin, 2009, p.242). Lebih lanjut Westwood (2011, p.188) menjelaskan expo- 
sitory adalah sebuah metode untuk menyajikan informasi baru secara langsung kepada siswa dalam bentuk yang dapat mereka mengerti. Metode expository termasuk demonstrasi, ceramah, penjelasan, menceritakan, siswa untuk membaca buku teks, menunjukkan video, atau meminta siswa untuk bekerja melalui presentasi dari komputer. Guru bersifat dominan, guru menentukan bagaimana siswa akan belajar.

Dari beberapa fakta yang ditemukan seperti guru masih menggunakan metode expository dalam pembelajaran matematika, metode pembelajaran yang digunakan belum memberikan pengalaman belajar seperti pada pendekatan saintifik, dan belum digunakannya metode Project-based learning dalam pembelajaran di kelas. Maka penelitian ini dibatasi pada penggunaan metode Project-based learning dibandingkan dengan metode expository dalam pengaruhnya terhadap hasil belajar matematika pada siswa kelas V SD di Gugus I Kecamatan Bantul. Penelitian ini bertujuan untuk mengetahui apakah ada perbedaan pengaruh antara siswa yang mendapat pembelajaran menggunakan metode Project-based learning dengan siswa yang mendapat pembelajaran menggunakan metode expository dilihat dari hasil belajar matematikanya.

\section{Metode}

\section{Jenis Penelitian}

Penelitian ini menggunakan pendekatan kuantitatif. Penelitian termasuk eksperimen semu. Desain yang digunakan adalah kelompok kontrol prates-pascates berpasangan.

\section{Waktu dan Tempat Penelitian}

Penelitian dilakukan pada bulan Februari 2015 s.d. Maret 2015. Penelitian dilakukan di SD 1 Bantul dan SD Bantul Warung yang termasuk pada wilayah gugus I Kecamatan Bantul, Kabupaten Bantul.

Populasi-sampel Penelitian

Populasi pada penelitian ini adalah seluruh kelas V SD yang berada pada Gugus I Kecamatan Bantul. Jumlah populasi adalah 11. Sampel dipilih menggunakan teknik probability sampling dengan jenis simple random sampling. Tiga kelas sampel dipilih secara acak dari populasi. Diperoleh kelas VA SD 1 Bantul sebagai kelas eksperimen 1 (KE1), kelas V SD Bantul Warung sebagai kelas eksperimen 2 (KE2), dan kelas VB SD 1 Bantul sebagai kelas kontrol (KK).
Prosedur

Penelitian termasuk eksperimen semu. Desain yang digunakan adalah kelompok kontrol prates-pascates berpasangan. Penelitian eksperimen semu ini dilakukan dengan menggunakan dua kelompok, yaitu kelompok eksperimen dan kelompok kontrol. Untuk menghindari hasil dari penelitian hanya bersifat kebetulan, kelompok eksperimen terdiri atas dua kelas eksperimen dan kelompok kontrol terdiri atas satu kelas kontrol. Kelas eksperimen akan mendapat perlakuan yang sama. Untuk melihat pengaruh dari perlakuan yang berbeda pada subyek penelitian didahului dengan pretest dan diakhiri dengan postest. Perbedaan antara pretest dan postest diasumsikan sebagai efek dari perlakuan atau eksperimen.

Gambaran penelitian (Sukmadinata, 2009, p.208) yang akan dilakukan dapat dilihat pada Tabel 1.

Tabel 1. Rancangan Penelitian

\begin{tabular}{cccc}
\hline Kelompok & Pretest & Perlakuan & Posttest \\
\hline KE1 & $\mathrm{O}_{1}$ & $\mathrm{X}_{1}$ & $\mathrm{O}_{2}$ \\
KE2 & $\mathrm{O}_{1}$ & $\mathrm{X}_{1}$ & $\mathrm{O}_{2}$ \\
KK & $\mathrm{O}_{1}$ & $\mathrm{X}_{1}$ & $\mathrm{O}_{2}$ \\
\hline
\end{tabular}

Keterangan:

$\mathrm{KE}_{1}$ : kelas eksperimen pertama dengan menggunakan metode Project-based learning

$\mathrm{KE}_{2}$ : kelas eksperimen kedua dengan menggunakan metode Project-based learning

KK: kelas kontrol dengan menggunakan metode Expository

$\mathrm{O}_{1}$ : tes awal (pretest)

$\mathrm{O}_{2}$ : tes akhir (postest)

$\mathrm{X}_{1}$ : pembelajaran dengan menggunakan metode Project-based learning

$\mathrm{X}_{2}$ : pembelajaraan dengan menggunakan metode expository

Data, Instrumen, dan Teknik Pengumpulan Data

Data merupakan data interval berupa skor hasil belajar matematika dalam ranah afektif, kognitif, dan psikomotor. Skor hasil belajar afektif dikumpulkan menggunakan angket penilaian diri sikap terhadap pelajaran matematika. Skor hasil belajar kognitif dikumpulkan menggunakan tes prestasi belajar. Sedangkan skor hasil belajar psikomotor dikumpulkan menggunakan observasi kemampuan bertindak setelah mendapatkan pelajaran. Pengumpulan data dilakukan melalui pretest dan posttest dari masing-masing kelompok sampel. 


\section{Jurnal Prima Edukasia, 4 (1), Januari 2016 - 111}

Noviarda Yastika, Haryanto

Teknik Analisis Data

Data dianalisis menggunakan teknik analisis data deskriptif dan kuantitatif. Analisa deskriptif digunakan untuk menyajikan data yang telah diperoleh melalui hasil pre-test dan post-test tes hasil belajar pada semua kelas eksperimen dan kelas kontrol. Analisis deskriptif disajikan dalam bentuk Tabel (mean, median, modus, standar deviasi, varian, skor minimum, dan skor maksimum).

Analisis kuantitatif digunakan untuk menguji hipotesis penelitian. Dalam penelitian ini teknik analisis kuantitatif yang digunakan adalah menggunakan MANOVA. MANOVA adalah teknik analisis yang digunakan untuk mengamati perbedaan rata-rata pada berbagai level (kategori) variabel independen dengan mempertimbangkan varians pada masing-masing kategori tersebut (Gudono, 2014, p.78). MANOVA digunakan karena jumlah variabel dependen lebih dari dua. Uji analisis terhadap data awal bertujuan untuk mengetahui kesamaan rata-rata skor perolehan siswa sebelum diberikan perlakuan, yang menunjukkan bahwa kemampuan kelompok itu sama. Sedangkan uji analisis terhadap data akhir bertujuan untuk melihat perbedaan rata-rata skor perolehan siswa setelah diberikan perlakuan, yang menunjukkan adanya perbedaan dari hasil perlakuan yang diberikan. Adapun hipotesis dalam penelitian ini adalah:

Ho: tidak ada perbedaan pengaruh pembelajaran menggunakan metode Project-based learning dan metode expository terhadap hasil belajar matematika pada siswa kelas V SD Gugus I Kecamatan Bantul.

Ha: ada perbedaan pengaruh pembelajaran menggunakan metode Project-based learning dan metode expository terhadap hasil belajar matematika pada siswa SD kelas V SD Gugus I Kecamatan Bantul.

Teknik analisis data dihitung dengan menggunakan bantuan SPSS 19.0 for windows.

\section{Hasil dan Pembahasan}

Hasil Penelitian

Data hasil penelitian berupa data pretest dan data posttest disajikan secara deskriptif. Hasil pretest dan posttest pada masing-masing kelompok sampel disajikan dalam tabel. Tabel 2 menyajikan data hasil pretest KE1. Tabel 3 menyajikan data hasil posttest dari KE1.
Tabel 2. Data Pretest KE1

\begin{tabular}{lrrr}
\hline & afektif & kognitif & psikomotor \\
\hline N Valid & 28 & 28 & 28 \\
$\quad$ Missing & 0 & 0 & 0 \\
Mean & 47.0000 & 60.5104 & 15.8571 \\
Median & 47.0000 & 65.7100 & 15.0000 \\
Mode & $44.00^{\mathrm{a}}$ & 65.71 & 14.00 \\
Std. Deviation & 6.05530 & 16.08817 & 4.53557 \\
Variance & 36.667 & 258.829 & 20.571 \\
Minimum & 35.00 & 20.00 & 7.00 \\
Maximum & 59.00 & 88.57 & 24.00 \\
\hline
\end{tabular}

Tabel 3. Data Hasil Posttest KE1

\begin{tabular}{lrrr} 
& afektif & kognitif & psikomotorik \\
\hline N Valid & 28 & 28 & 28 \\
$\quad$ Missing & 0 & 0 & 0 \\
Mean & 50.2500 & 88.3168 & 20.1786 \\
Median & 51.0000 & 92.8600 & 21.5000 \\
Mode & 56.00 & 100.00 & $23.00 \mathrm{a}$ \\
Std. Deviation & 5.16846 & 13.36720 & 3.76193 \\
Variance & 26.713 & 178.682 & 14.152 \\
Minimum & 38.00 & 54.29 & 10.00 \\
Maximum & 59.00 & 100.00 & 24.00 \\
\hline
\end{tabular}

Dari hasil perbandingan Tabel 2 dan Tabel 3 dapat diketahui bahwa pada KE1 terdapat perbedaan dari rata-rata skor hasil belajar afektif, kognitif, dan psikomotor. Pada hasil belajar afektif terjadi peningkatan rata-rata dari 47 menjadi 50,25. Pada hasil belajar kognitif terjadi peningkatan rata-rata dari 60,51 menjadi 88,31 . Sedangkan pada hasil belajar psikomotor terjadi peningkatan rata-rata dari 18,85 menjadi 20,17 .

Data hari KE2 disajikan pada Tabel 4 dan Tabel 5. Tabel 4 menunjukkan data pretest dari KE2. Sedangkan Tabel 5 menunjukkan data posttest KE2.

Tabel 4. Data Hasil Pretest KE2

\begin{tabular}{lrrr} 
& afektif & kognitif & psikomotor \\
\hline N Valid & 32 & 32 & 32 \\
$\quad$ Missing & 0 & 0 & 0 \\
Mean & 48.8125 & 57.6791 & 16.9688 \\
Median & 48.0000 & 57.1400 & 16.5000 \\
Mode & $43.00^{\mathrm{a}}$ & $37.14^{\mathrm{a}}$ & 16.00 \\
Std. Deviation & 6.06118 & 17.11988 & 2.66984 \\
Variance & 36.738 & 293.090 & 7.128 \\
Minimum & 35.00 & 31.43 & 13.00 \\
Maximum & 61.00 & 94.29 & 23.00 \\
\hline
\end{tabular}

a. Multiple modes exist. The smallest value is shown 
Tabel 5. Data Hasil Posttest KE2

\begin{tabular}{lrrr}
\hline & afektif & kognitif & psikomotor \\
\hline N Valid & 32 & 32 & 32 \\
\multicolumn{1}{c}{ Missing } & 0 & 0 & 0 \\
Mean & 53.6563 & 79.9997 & 21.5625 \\
Median & 54.5000 & 78.5700 & 22.0000 \\
Mode & 56.00 & $74.29^{\mathrm{a}}$ & 23.00 \\
Std. Deviation & 4.86335 & 12.42086 & 2.21341 \\
Variance & 23.652 & 154.278 & 4.899 \\
Minimum & 43.00 & 57.14 & 16.00 \\
Maximum & 61.00 & 100.00 & 24.00 \\
\hline
\end{tabular}

a. Multiple modes exist. The smallest value is shown

Tabel 4 dan Tabel 5 menunjukkan perbandingan skor pretest dan posttest dari KE2. Terjadi peningkatan rata-rata hasil belajar afektif dari 48,81 menjadi 53,65. Pada hasil belajar kognitif terjadi peningkatan dari 56, 67 menjadi 79,99. Begitu pula pada hasil belajar psikomotor terjadi peningkatan dari 16,96 menjadi 21,56 .

Data hari KK disajikan pada Tabel 6 dan Tabel 7. Tabel 6 menunjukkan data pretest dari KK. Sedangkan Tabel 7 menunjukkan data posttest $\mathrm{KK}$.

Tabel 6. Data Hasil Pretest KK

\begin{tabular}{lrrr}
\hline & afektif & kognitif & psikomotor \\
\hline $\mathrm{N} \quad$ Valid & 28 & 28 & 28 \\
\multicolumn{1}{c}{ Missing } & 0 & 0 & 0 \\
Mean & 46.7857 & 65.8157 & 17.4286 \\
Median & 48.5000 & 67.1400 & 17.5000 \\
Mode & $42.00^{\mathrm{a}}$ & 68.57 & $18.00^{\mathrm{a}}$ \\
Std. Deviation & 6.69636 & 14.78365 & 3.30464 \\
Variance & 44.841 & 218.556 & 10.921 \\
Minimum & 35.00 & 31.43 & 12.00 \\
Maximum & 56.00 & 85.71 & 23.00 \\
\hline
\end{tabular}

a. Multiple modes exist. The smallest value is shown

Tabel 7. Data Hasil Posttest KK

\begin{tabular}{lrrr}
\hline & afektif & kognitif & psikomotorik \\
\hline N Valid & 28 & 28 & 28 \\
$\quad$ Missing & 0 & 0 & 0 \\
Mean & 46.1786 & 71.7339 & 19.0000 \\
Median & 47.5000 & 68.5700 & 19.5000 \\
Mode & $38.00^{\mathrm{a}}$ & $60.00^{\mathrm{a}}$ & 22.00 \\
Std. Deviation & 6.58873 & 12.23002 & 2.99382 \\
Variance & 43.411 & 149.573 & 8.963 \\
Minimum & 35.00 & 48.57 & 13.00 \\
Maximum & 56.00 & 91.43 & 23.00 \\
\hline
\end{tabular}

Tabel 6 dan Tabel 7 menunjukkan perbandingan skor pretest dan posttest dari KE2. Terjadi penurunan rata-rata hasil belajar afektif dari 46,78 menjadi 46,17. Pada hasil belajar kognitif terjadi peningkatan dari 65,81 menjadi 71,73. Begitu pula pada hasil belajar psiko- motor terjadi peningkatan dari 17,42 menjadi 19,00 .

Perbedaan skor pretest dan posttest dari masing-masing kelompok sampel kemudian dihitung tingkat kenaikan berdasarkan skor gain dinormalisasi hake (1998, p.65). Tabel 8 menyajikan data peningkatan skor dari masingmasing kelompok sampel.

Tabel 8. Data Peningkatan

Skor Pretest dan Posttest

\begin{tabular}{lccc}
\hline & \multicolumn{3}{c}{ Hasil belajar } \\
\cline { 2 - 4 } Kelas & Afektif & Kognitif & Psikomotor \\
\cline { 2 - 4 } & gain & gain & gain \\
\hline KE1 & 0.19 & 0.70 & 0.53 \\
KE2 & 0.32 & 0.53 & 0.86 \\
KK & -0.04 & 0.17 & 0.22 \\
\hline
\end{tabular}

Data kemudian dianalisis secara kuantitatif menggunakan teknik MANOVA. Data pretest dianalisis dengan tujuan untuk menunjukkan bahwa pada kemampuan awal ketiga kelompok sampel mempunyai kemampuan yang sama. Hasil dari uji pra syarat pada data pretest yaitu uji normalitas dan homogenitas menunjukkan bahwa data normal dan homogen. Hasil uji normalitas disajikan pada Tabel 9.

Tabel 9. Uji Normalitas Data Pretest

\begin{tabular}{clcl}
\hline Kelas & \multicolumn{1}{c}{ Data } & $\begin{array}{c}\text { Taraf sig, } \\
\text { Kolmog- } \\
\text { Smirnov }\end{array}$ & Simpulan \\
\hline \multirow{2}{*}{ KE1 } & Skor afektif & 1,000 & Normal \\
& Skor kognitif & 0,222 & Normal \\
& Skor psikomotor & 0,759 & Normal \\
KE2 & Skor afektif & 0,811 & Normal \\
& Skor kognitif & 0,648 & Normal \\
& Skor psikomotor & 0,542 & Normal \\
KK & Skor afektif & 0,566 & Normal \\
& Skor kognitif & 0,707 & Normal \\
& Skor psikomotor & 0,961 & Normal \\
\hline
\end{tabular}

Hasil uji homogenitas varian disajikan pada Tabel 10. Dari hasil uji homogenitas dapat disimpulkan bahwa data bersifat homogen. Sedangkan dari uji homogenitas kovarian dihasilkan signifikansi atau $\mathrm{p}=0,68$. Karena signifikansi lebih besar dari 0.05 maka hasil belajar afektif pretest, hasil belajar kognitif pretest, dan hasil belajar psikomotor pretest pada KE1, KE2, dan KK mempunyai kovarian yang homogen. Dengan demikian analisis MANOVA dapat dilakukan. 
Tabel 10. Hasil Uji homogenitas Data Pretest

\begin{tabular}{lcccc}
\hline & Levene Statistic df1 df2 Signifikansi \\
\hline afektif & .846 & 2 & 85 & .433 \\
kognitif & 1.325 & 2 & 85 & .271 \\
psikomotor & 2.196 & 2 & 85 & .118 \\
\hline
\end{tabular}

Hasil uji multivariat MANOVA menunjukkan bahwa taraf signifikansi dari empat uji statistik Pilai's Trace, Wilks' Lambda, Hotelling 's Trace dan Roy's pada variabel kelas adalah 0,081, 0,082, 0,084, dan 0,041 Semua menunjukkan taraf $\mathrm{Sig}>\alpha(0,05)$. maka $\mathrm{H}_{0}$ diterima. Tidak ada perbedaan rata-rata hasil belajar afektif, kognitif, dan psikomotor dari KE (KE1 dan KE2) dan KK. Jadi rata-rata hasil belajar sebelum dilakukan perlakuan adalah sama. Dapat disimpulkan bahwa kemampuan awal dari KE1, KE2, dan KK adalah sama.

Analisis selanjutnya dilakukan pada data posttest. Sebelum dilakukan analisis menggunakan teknik MANOVA dilakukan uji pra syarat terlebih dahulur yang meliputi uji normalitas dan uji homogenitas. Tabel 11 menyajikan hasil dari uji normalitas data posttest.

Tabel 11. Hasil Uji Normalitas Data Posttest

\begin{tabular}{clcl}
\hline Kelas & \multicolumn{1}{c}{ Jenis data } & $\begin{array}{c}\text { Taraf sig, } \\
\text { Kolmog- } \\
\text { Smirnov }\end{array}$ & Simpulan \\
\hline KE1 & Skor afektif & 0,968 & Normal \\
& Skor kognitif & 0,127 & Normal \\
& Skor psikomotor & 0,245 & Normal \\
KE2 & Skor afektif & 0,722 & Normal \\
& Skor kognitif & 0,605 & Normal \\
& Skor psikomotor & 0,117 & Normal \\
KK & Skor afektif & 0,574 & Normal \\
& Skor kognitif & 0,528 & Normal \\
& Skor psikomotor & 0,635 & Normal \\
\hline
\end{tabular}

Dari hasil uji normalitas dapat disimpulkan bahwa data posttest berdistribusi normal. Kemudian dilanjutkan dengan uji homogenitas varian dan kovarian. Dari uji homogenitas menggunakan SPSS 19.0 dapat diketahui bahwa taraf signifikansi levene statistic data posttest hasil belajar afektif, kognitif, dan psikomotor adalah 0,060, 0,954, dan 0,318 sehingga dapat disimpulkan bahwa semua data posttest homogen. Uji homogenitas kovarian dilakukan dengan melihat hasil analisis dari tes Box's $M$. hasilnya diperoleh signifikansi atau $\mathrm{p}$ $=0,222$. Karena signifikansi lebih besar dari 0,05 maka hasil belajar afektif, hasil belajar kognitif, dan hasil belajar psikomotor pada KE1, KE2, dan KK mempunyai kovarian yang homogen. Dari hasil ini proses analisis
MANOVA dapat dilakukan untuk menguji hipotesis penelitian.

Hasil uji multivariat MANOVA menunjukkan bahwa taraf signifikansi dari empat uji statistik Pilai's Trace, Wilks' Lambda, Hotelling's Trace dan Roy's pada variabel kelas adalah 0,000. Semua menunjukkan taraf Sig $(0,000)<\alpha(0,05)$. Terdapat perbedaan rata-rata hasil belajar siswa (hasil belajar afektif, hasil belajar kognitif, dan hasil belajar psikomotor) diantara kelas eksperimen dengan kelas kontrol. Sehingga dapat disimpulkan bahwa metode pembelajaran yang digunakan berpengaruh terhadap hasil belajar siswa (hasil belajar afektif, hasil belajar kognitif, dan hasil belajar psikomotor).

Hasil pengujian secara terpisah (univariat) merupakan lanjutan dari uji multivariat MANOVA. Pada Tabel Test of Between-Subjects Effects menunjukkan taraf $\mathrm{F}$ dan signifikansi pengaruh variabel independen yaitu kelas/ metode pembelajaran terhadap ketiga variabel dependen yaitu hasil belajar afektif, hasil belajar kognitif, dan hasil belajar psikomotor. Pada pengaruh metode pembelajaran terhadap hasil belajar afektif taraf mean square 417,570, taraf F 13,513, dan taraf signifikansi 0,000. Karena taraf signifikansi $<\alpha(0,05)$ maka terdapat perbedaan yang signifikan rata-rata hasil belajar afektif antara kelas yang mendapat metode PBL dengan kelas metode expository. Pengaruh metode pembelajaran terhadap hasil belajar kognitif mempunyai taraf mean square 1924,945 , taraf F 11,991, dan taraf signifikansi 0,000 . Karena taraf signifikansi $<\alpha(0,05)$ maka terdapat perbedaan yang signifikan rata-rata hasil belajar kognitif antara kelas yang mendapat metode PBL dengan kelas metode expository. Begitu pula pada pengaruh metode pembelajaran terhadap hasil belajar psikomotor mempunyai taraf mean square 49,367, taraf $\mathrm{F}$ 5,408 dan taraf signifikansi 0,006. Hal ini berarti Karena taraf signifikansi $<\alpha(0,05)$ maka terdapat perbedaan yang signifikan ratarata hasil belajar kognitif antara kelas yang mendapat metode PBL dengan kelas metode expository.

Hasil pengujian terpisah lanjutan Post Hoc Tests menunjukkan perbedaan antar kelompok sampel dari hasil belajar berdasarkan kelas/metode pembelajaran. Dalam penelitian ini yang dilihat adalah perbedaan yang terjadi antara kelas eksperimen (KE1 dan KE2) dengan kelas kontrol (KK). Uji lanjutan yang digunakan teknik Tukey HSD. Adanya 


\section{Jurnal Prima Edukasia, 4 (1), Januari 2016 - 114}

Noviarda Yastika, Haryanto

perbedaan yang signifikan ditunjukkan dengan taraf signifikansi Kurang dari 0,05. Tabel 12 menunjukkan hasil uji lanjutan.

Tabel 12. Hasil Uji Lanjutan Post Hoc

\begin{tabular}{|c|c|c|c|}
\hline $\begin{array}{l}\text { Variabel } \\
\text { tergantung }\end{array}$ & $\begin{array}{l}(\mathrm{I}) \quad(\mathrm{J}) \\
\text { kelaskelas }\end{array}$ & $\begin{array}{l}\text { Perbedaan } \\
\text { rata-rata (I-J }\end{array}$ & \\
\hline \multirow[t]{2}{*}{ afektif } & KE1 KK & 4,0714 & 0,020 \\
\hline & KE2 KK & 7,4777 & 0,000 \\
\hline \multirow{2}{*}{ kognitif } & KE1 KK & 16,5829 & 0,000 \\
\hline & KE2 KK & 8,2658 & 0,036 \\
\hline \multirow{2}{*}{ psikomotor } & KE1 KK & 1,1785 & 0,016 \\
\hline & KE2 KK & 2,5625 & 0,004 \\
\hline
\end{tabular}

Hasil analisis Tukey HSD menunjukkan ada perbedaan rata-rata hasil belajar afektik KE1 dan KK. Rata-rata hasil belajar afektif KE1 lebih tinggi dibanding rata-rata hasil belajar afektif $\mathrm{KK}$ dengan taraf mean difference 4,0714 dan signifikan pada signifikansi $0,020<$ $\alpha(0,05)$. Ada perbedaan yang signifikan antara hasil belajar afektif antara KE1 dan KK. Hal ini menunjukkan bahwa hasil belajar afektif KE1 lebih baik dari KK. Begitu pula pada perbedaan rata-rata hasil belajar kognitif KE1 lebih tinggi dari rata-rata hasil belajar kognitif KK dengan taraf mean difference 16,5829 dan signifikan pada signifikansi $0,000<\alpha(0,05)$. Ada perbedaan yang signifikan antara hasil belajar kognitif antara KE1 dan KK. Hasil belajar kognitif KE1 lebih baik dari pada hasil belajar kognitif KK. Perbedaan rata-rata hasil belajar psikomotorik KE1 lebih tinggi dari $\mathrm{KK}$ dengan mean difference 1,1785 dan signifikan pada signifikansi $0,016<\alpha(0,05)$. Ada perbedaan yang signifikan antara hasil belajar psikomotor antara KE1 dan KK. Jadi hasil belajar psikomotor KE1 lebih baik dari pada hasil belajar psikomotor KK.

Demikian pula rata-rata hasil belajar afektif KE2 lebih tinggi dari rata-rata hasil belajar afektif KK dengan taraf mean difference 7,4777 dan signifikan pada signifikansi $0,000<$ $\alpha(0,05)$. Ada perbedaan yang signifikan antara hasil belajar afektif antara KE2 dan KK. Dari hasil perhitungan dapat disimpulkan bahwa KE2 mempunyai hasil belajar afektif yang lebih baik dari pada KK. Pada perbedaan rata-rata hasil belajar kognitif KE2 lebih tinggi daripada rata-rata hasil belajar kognitif KK dengan taraf mean difference 8,2658 dan signifikan pada signifikansi $0,036<\alpha(0,05)$. Ada perbedaan yang signifikan antara hasil belajar kognitif antara KE2 dan KK. Hasil belajar konitif KE2 lebih baik dari hasil belajar kognitif KK. Begitu pula perbedaan rata-rata hasil belajar psiko- motor KE2 lebih tinggi dari KK dengan mean difference 2,5625 dan signifikan pada signifikansi $0,004<\alpha(0,05)$. Ada perbedaan yang signifikan antara hasil belajar psikomotor antara KE2 dan KK. Sehingga dapat disimpulkan hasil belajar psikomotor KE2 lebih baik jika dibandingkan dengan hasil belajar psikomotor KK.

\section{Pembahasan}

Hasil analisis deskriptif dan uji hipotesis menunjukkan adanya perbedaan yang signifikan pada hasil belajar afektif dari kelas eksperimen (KE1 dan KE2) dengan kelas kontrol (KK) menunjukkan bahwa metode yang digunakan pada proses pembelajaran berpengaruh terhadap hasil belajar siswa. Pada metode Project-based learning siswa dilibatkan dan mempunyai peran yang lebih banyak dari pada metode expository.

Menurut pendapat Davis (2009, p.218) bahwa siswa yang berpartisipasi dalam pembelajaran berbasis proyek lebih termotivasi, menunjukkan keterampilan komunikasi dan keterampilan kerja sama tim yang lebih baik, dan memiliki pemahaman yang lebih baik tentang isu-isu dan bagaimana menerapkan mereka belajar untuk masalah realistis. Diperkuat dengan pendapat Moore (2012, p.342) mengatakan setelah siswa memilih proyeknya maka motivasi belajar dan pembelajarannya akan meningkat dari sebelumnya. Adanya kesempatan untuk menyampaikan pendapat, memilih, dan menyesuaikan cara bekerja dengan diri sendiri memberikan motivasi untuk menyelesaikan proyeknya. Seperti yang disampaikan Knight (2013, p.230) bagi sebagian siswa adanya peningkatan kesempatan berbicara dalam pembelajaran akan membawa pada peningkatan motivasi. Begitu pula seperti yang disimpulkan oleh Anindyta \& Suwarjo (2014, p.125) pembelajaran yang memberikan kemandirian kepada siswa dapat meningkatkan kemampuan diri siswa untuk mengatur diri sendiri seperti kemandirian dan bertanggung jawab.

Metode Project-based learning yang dilakukan di kelas eksperimen melibatkan siswa dari awal kegiatan proyek. Siswa akan termotivasi memberikan pendapat, gagasan, atau ide untuk melaksanakan proyek mereka. Pembelajaran menyenangkan karena siswa yang menentukan bagaimana dan darimana akan belajar. Melibatkan siswa dalam sebuah permasalahan yang membutuhkan penyelidikan seolah-olah mereka menjadi seorang ahli dalam bidang tertentu. Sehingga siswa menyukai belajar, 
mereka senang melakukannya. Hal ini sejalan dengan penelitian sebelumnya yang menyimpulkan bahwa pembelajaran Project-based learning dapat meningkatkan motivasi belajar (Filippatou dan Kaldi, 2010, p.25; Chikita et, al. 2013, p.9).

Siswa dalam kelas eksperimen membentuk sebuah komunitas dalam bentuk kelompok di mana mereka akan bekerja sama, saling membagi tugas, dan bertanggung jawab terhadap apa yang mereka lakukan. Seperti yang telah dijelaskan Bender (2012, p.52) bahwa pengetahuan untuk bekerja dalam sebuah kelompok untuk menyelesaikan suatu masalah adalah keterampilan yang penting untuk dikembangkan, dalam Project-based learning siswa akan belajar bagaimana melakukan hal itu. Siswa berusaha mendapatkan informasi yang paling tepat yang dapat mereka temukan untuk menyusun produk atau menemukan solusi dari permasalahan, dalam proses ini siswa memerlukan ketelitian dan membutuhkan banyak sumber informasi. Pada proses ini siswa mengalami pengalaman untuk menghargai pendapat, peduli terhadap orang lain, melatih ketelitian, tidak menyerah dan disiplin. Pengaruh ini sesuai dengan hasil penelitian Chikita et, al. (2013, p.9) yang menyimpulkan bahwa pembelajaran Project-based learning dapat meningkatkan disiplin belajar siswa. Demikian pula hasil penelitian dari Wahyudi \& Suardiman (2013, p.122)yang menjelaskan bahwa karakter kejujuran, kerja sama, tanggung jawab dapat dikembangkan melalui pembelajaran yang melibatkan siswa secara aktif dan mendapat peran tertentu.

Penelitian Erdogan, Bayram \& Deniz, (2013, p.42) menunjukkan pembelajaran melibatkan berbagai sumber seperti internet, perpustakaan, museum, arsip-arsip dan sumber lain sebagai sumber belajar yang dapat diakses oleh siswa dapat meningkatkan hasil belajar dan sikap siswa. Sejalan dengan itu siswa dalam kelas eksperimen mempunyai kesempatan dan pengalaman belajar untuk mencari sumber belajar yang beragam. Siswa melibatkan berbagai sumber belajar menurut apa yang siswa penting dan senangi. Sehingga siswa mempunyai minat yang baik untuk belajar.

Setelah mendapatkan informasi siswa melakukan analisis dan mengambil kesimpulan terhadap beberapa informasi yang sudah didapatkan. Dalam prosesnya siswa bersama kelompoknya melakukan evaluasi terhadap produk yang dihasilkan, mendengarkan saran dan pendapat orang lain agar produk menjadi lebih baik. Proses revisi dilakukan agar produk menjadi lebih baik. Mereka menggunakan pengetahuan yang mereka dapat dari guru atau sumber lainnya untuk menyusun dan menciptakan produk dari proyek mereka. Pada akhirnya siswa bersama kelompoknya menyajikan karya mereka dalam presentasi yang telah dipersiapkan sebelumnya.

Sejalan dengan hasil penelitian oleh Tseng, Chang, Lou. et al. (2013, p.100) serta Han et, al. (2014, p.19-20) bahwa siswa memiliki sikap positif terhadap matematika setelah mendapatkan pengalaman belajar Project-based learning. Siswa dalam kelas eksperimen mempunyai minat belajar matematika meningkat. Siswa benar-benar menyadari pentingnya matematika. Mereka mengakui bahwa matematika adalah subjek mendasar yang penting untuk belajar, sehingga mereka harus belajar matematika.

Pengalaman belajar seperti Project-based learning tidak ditemukan dalam proses pembelajaran yang menggunakan metode expository. Sebagaimana Martin (2009, p.243) menjelaskan metode expository termasuk metode yang bersifat teacher-centered. Guru memutuskan apa yang harus diajarkan. Semua kegiatan ini berfokus pada guru. Apa yang dikatakan guru adalah apa yang harus dipelajari; guru adalah sumber dan pemilik pengetahuan. Para siswa mungkin atau mungkin tidak terlibat secara kognitif, dan guru tidak memiliki cara untuk mengetahui kecuali untuk berhenti dan meminta siswa untuk meringkas karena mereka akan ketika membaca cerita-dan bahkan kemudian, pemahaman yang diinternalisasi oleh siswa mungkin tidak terlihat.

Dalam pembelajaran expository siswa tidak terlibat aktif dalam pembelajaran. Siswa tidak mempunyai kesempatan belajar dengan apa yang mereka pilih dan sukai. Siswa bekerja dengan diri mereka sendiri, siswa tidak punya kesempatan untuk berbagi dengan temannya. Sumber belajar terbatas pada guru dan apa yang disampaikan oleh guru. Ketika ada permasalahan yang cukup sulit maka siswa akan berada pada tekanan yang tinggi. Sedangkan ketika ada permasalahan yang cukup mudah akan membuat siswa bosan. Tidak ada kesempatan yang diberikan berupa tantangan kepada diri siswa untuk berupaya memecahkan masalah dengan berpikir keluar dari kelas.

Begitu pula pada hasil belajar kognitif. Pada pembelajaran Project-based learning menekankan pada pengalaman belajar siswa. Guru 


\section{Jurnal Prima Edukasia, 4 (1), Januari 2016 - 116}

Noviarda Yastika, Haryanto

tidak memberikan pelajaran secara langsung, guru mendesain proyek, menyiapkan dan memandu siswa dan belajar bersama siswa selama proyek. Berbeda dengan metode expository di mana guru memberikan memberikan pelajaran secara langsung dan berpusat kepadanya.

Prinsip-prinsip dalam Project-based learning sebagai mana disampaikan oleh Thomas (Knight, 2013, p.227). Membantu siswa mengembangkan kemampuan kognitifnya. Prinsip sentralistis menegaskan bahwa siswa dari kelas eksperimen belajar konsep pengetahuan dari proyek yang dikerjakan. Siswa belajar konsep-konsep ilmu melalui proyek. Berbeda dengan kelas kontrol yang mendapat konsepkonsep dari penjelasan guru. Menurut Knight (2013, p.231) siswa yang terlibat dalam pengalaman dunia nyata akan mempunyai ingatan yang baik tentang apa yang mereka pelajari.

Proyek yang dikerjakan siswa pada pembelajaran Project-based learning berfokus pada pertanyaan atau masalah yang mengarahkan siswa untuk menghadapi dan berjuang dengan konsep dan prinsip-prinsip suatu disiplin ilmu (prinsip pertanyaan pendorong). Guru memberikan pertanyaan yang mendorong siswa untuk membangun pengetahuannya sendiri untuk memecahkan persoalan atau masalah proyek yang dihadapinya. Siswa menggunakan pengetahuan yang sudah ada dam mencari pengetahuan melalui informasi-informasi untuk merancang dan membuat produk. Hal ini sejalan dengan pendapat Piaget dan Vygotsky (Slavin, 2006, p.243) dalam teori belajar konstruktivistik bahwa perubahan kognitif terjadi hanya ketika konsepsi sebelumnya melalui proses disequilibrasi ketika berhubungan dengan informasi baru.

Prinsip investigasi konstruktif yaitu melibatkan siswa dalam penyelidikan. Sebuah proses yang diarahkan pada tujuan yang melibatkan penyelidikan, membangun pengetahuan, perancangan, pengambilan keputusan, menemukan masalah, pemecahan masalah, hingga penyelesaian. Siswa dalam kelas eksperimen didorong untuk mengonstruksi pengetahuan sendiri untuk memecahkan persoalan yang dihadapinya. Berdasarkan pendapat Laur (2013, pp.4-5) dengan memberikan siswa pengalaman belajar untuk melakukan penyelidikan yang menantang adalah sangat penting bagi keterlibatan siswa. Proses ini harus disesuaikan untuk menciptakan keinginan bagi siswa untuk menggali secara mendalam terhadap materi dan standar pembelajaran.
Siswa mendapatkan pengalaman belajar secara mandiri (prinsip otonomi). Siswa dalam kelas eksperimen mempunyai kebebasan menentukan pilihannya sendiri, bekerja dengan mengatur waktu sendiri, dan bertanggung jawab. Guru berperan sebagai fasilitator dan mendorong tumbuhnya kemandirian siswa. Selain itu prinsip realistis yang berarti bahwa siswa bekerja dengan proyek yang realistik dan menggunakan dunia nyata sebagai sumber belajar.

Proses yang dialami oleh siswa dalam pengalaman belajar dalam Project-based learning berpengaruh terhadap peningkatan hasil belajar. Sejalan dengan penelitian sebelumnya (Gultekin, 2005, p.552; Han et, al., 2014, pp.1920) yang disimpulkan bahwa hasil belajar siswa mengalami peningkatan setelah siswa terlibat dalam pembelajaran menggunakan Projectbased learning. Hasil belajar siswa didukung aktivitas belajar yang tinggi, meliputi pencarian informasi, menganalisis informasi, bekerja sama dan berdiskusi dengan kelompok, hingga menampilkan produk. Hal ini sesuai dengan hasil penelitian Romanov dan Nevgi (2008, p.159) yang menyimpulkan bahwa hasil belajar yang lebih baik berhubungan dengan aktivitas belajar yang tinggi.

Pengalaman belajar siswa dalam kelas eksperimen sesuai dengan pendapat bahwa Project-based learning meningkatkan motivasi untuk belajar, bekerja sama, keterampilan kolaborasi, dan membawa siswa pada tingkat prestasi yang lebih tinggi (Bender, 2012, p.8) sehingga perubahan yang terjadi dalam proses kognitif siswa tinggi. Berbeda dengan siswa pada kelas kontrol di mana siswa mendapatkan konsep-konsep ilmu pengetahuan dengan cara yang sama dan satu sumber yang dominan yaitu guru sehingga perubahan kognitifnya lebih rendah dari siswa yang berada pada kelas eksperimen. Hal ini sejalan dengan pendapat pengajaran expository memiliki kekurangan yang serius, menurut Martin (2009, p.243) kelemahannya termasuk tingkat ketidakpastian perhatian siswa, kurang menyesuaikan pelajaran dengan kebutuhan masing-masing siswa, ketidakmampuan siswa untuk mengikuti aliran dari pelajaran pada kecepatan yang sama, dan kurangnya potensi relevansi materi dengan kehidupan siswa.

Adanya perbedaan pada hasil belajar psikomotor menunjukkan bahwa penggunaan metode Project-based learning berpengaruh terhadap hasil belajar psikomotor siswa. Parkay 
(2010, p.387) menjelaskan bahwa dalam pembelajaran Project-based learning menuntut siswa untuk membangun pengetahuannya dengan mengelola dan mengaplikasikan berbagai sumber informasi untuk memecahkan suatu permasalahan (problem solving). Siswa pada kelas eksperimen mempunyai kebebasan dan kemandirian untuk menggunakan berbagai sumber belajar dalam mengerjakan proyeknya sehingga keterampilan memecahkan masalah mereka berkembang dengan lebih baik. Berbeda dengan siswa pada kelas kontrol yang tidak mendapatkan pengalaman seperti ini.

Pembelajaran Project-based learning dipandang sebagai salah satu pembelajaran yang mendorong motivasi siswa untuk membangun pengetahuan dan keterampilan (Davis, 2009, p.218). Siswa membentuk komunitas dan melakukan kerja sama dengan orang lain. Mendapatkan pengalaman menyampaikan ide, mendengarkan ide orang lain, menemukan masalah dan kemudian mencari pemecahannya. Siswa berlatih berpikir sistematis dan logis untuk mengerjakan proyeknya. Dari proses ini Project-based learning membantu siswa meningkatkan keterampilan memecahkan masalah dengan cara yang sistematis. Hal ini sejalan dengan penelitian yang telah dilakukan dan menyimpulkan bahwa pembelajaran Projectbased learning dapat meningkatkan keterampilan menyelesaikan masalah (Gultekin, 2005, p.552; Mettas dan Constantinou, 2007, p.99; Karaman dan Celik, 2008, p.213; Holm, 2011, p.10).

Hasil belajar psikomotor berkaitan dengan kemampuan bertindak setelah siswa menerima pengalaman belajar tertentu. Hasil belajar psikomotor merupakan tahap lanjutan dari hasil belajar afektif yang baru tampak kecenderungan untuk berperilaku (Sudjana, 2013, p.31). Proses yang dialami siswa dalam Project-based learning memungkinkan siswa untuk meningkatkan keterampilan mendapatkan informasi, keterampilan komunikasi, keterampilan kerjasama, keterampilan mengorganisasi diri melalui kegiatan-kegiatan berdasarkan prinsip-prinsip pembelajaran Project-based learning.

Sesuai dengan Jerome Bruner (Martin, 2009 , p.243) yang berpendapat bahwa pengajaran expository membuat siswa pasif. Ia juga mencontohkan beberapa kelemahan tambahan untuk pengajaran expository seperti hasil pengajaran expository mengurangi kemampuan dalam menggunakan material dan proses berpikir di luar kelas. Siswa pada kelas kontrol mendapat pembelajaran di dalam kelas yang membuat siswa pasif, sehingga siswa kurang berlatih dalam mengembangkan kemampuan-kemampuan psikomotornya dan keterampilan pemecahan masalah. Guru dominan menjadi sumber belajar dan kurang memberikan kesempatan kepada siswa.

Metode expository menjadikan pembelajaran berpusat pada guru. Siswa kurang berpartisipasi dan kurang terlibat dalam pembelajaran. Aktivitas belajar yang rendah menyebabkan peningkatan hasil belajar yang lebih rendah dibandingkan siswa yang mendapat metode Project-based learning di mana siswa mendapat kesempatan untuk terlibat secara aktif dalam pembelajaran. Hal ini sejalan dengan hasil penelitian (Sigler dan Saam, 2007, p.28; Edinyang dan Ubi, 2012, p.100; Helen, 2013, p.54) yang menyimpulkan bahwa hasil belajar siswa dalam kelas yang mendapat pembelajaran expository tidak lebih baik dari hasil belajar siswa yang mendapat pembelajaran di kelas yang membeikan kesempatan kepada siswa untuk terlibat aktif dalam pembelajaran.

\section{Simpulan dan Saran}

\section{Simpulan}

Adanya perbedaan yang signifikan dari rata-rata hasil belajar siswa yang mendapatkan metode pembelajaran Project-based learning dibandingkan dengan siswa yang mendapat metode expository. Rata-rata hasil belajar menggunakan metode Project-based learning lebih baik daripada metode expository. Penggunaan metode Project-based learning lebih efektif dalam meningkatkan hasil belajar jika dibandingkan dengan penggunaan metode expository.

Penggunaan metode pembelajaran berpengaruh terhadap hasil belajar siswa. Siswa yang mempunyai kesempatan untuk belajar mandiri dan sumber belajar yang beragam mempunyai kesempatan yang lebih baik untuk mengembangkan kemampuannya dalam menerima dan menggunakan konsep-konsep ilmu pengetahuan. Siswa akan mengembangkan sikap-sikap bagaimana mereka harus belajar dan berhubungan dengan lingkungannya. Keterampilanketerampilan siswa dalam memecahkan masalah, bekerja sama dan mencari informasi berkembang positif sejalan dengan perkembangan kognitif mereka.

\section{Saran}




\section{Jurnal Prima Edukasia, 4 (1), Januari 2016 - 118}

Noviarda Yastika, Haryanto

Saran dari hasil penelitian ini adalah sekolah sebaiknya menyusun kurikulum sekolah dan menganggarkan fasilitas untuk implementasi metode Project-based learning sebagai salah satu metode yang digunakan dalam proses pembelajaran. Hal ini agar memotivasi guru untuk menggunakan metode pembelajaran yang bervariasi dan tidak monoton. Kemudian penggunaan metode pembelajaran berpengaruh terhadap hasil belajar. Guru sebaiknya dapat memilih metode yang tepat untuk menyampaikan suatu materi. Penggunaan metode tradisional seperti expository mungkin mempunyai beberapa keuntungan dan sesuai terhadap materi tertentu. Tetapi menggunakan metode yang berpusat kepada siswa seperti Project-based learning mempunyai hasil dan pengaruh yang lebih baik. Serta siswa dalam belajar menggunakan sumber informasi sebanyak mungkin. Ketika bertemu banyak informasi siswa dapat menganalisis informasi dan mengambil generalisasi, atau mungkin melakukan seleksi terhadap informasi tersebut. Dengan demikian siswa akan mengembangkan kemampuan-kemampuan belajarnya.

\section{Daftar Pustaka}

Anindyta, P., \& Suwarjo, S. (2014). Pengaruh problem based learning terhadap keterampilan berpikir kritis dan regulasi diri siswa kelas V. Jurnal Prima Edukasia, 2(2), 209-222. (Diakses melalui http://journal.uny.ac.id/index.php/jpe/ article/view/2720 pada hari Selasa, 14 Juli 2015)

Bender, W. N. (2012). Project-based learning differentiating instruction for the 21st century. Thousand Oaks: Corwin

Chikita, G. P., et.al. (2013). The effect of project-based learning and students' perceived learning discipline toward the writing competency of the eleventh grade students of SMAN 5 Mataram in the academic year 2012/2013. Diambil pada tanggal 22 April 2015 dari http://pasca.undiksha.ac.id/ejournal/index.php/jpbi/article/downloa $\underline{\mathrm{d} / 747 / 533}$

Edinyang \& Ubi. (2012). Relative effectiveness of inquiry and expository methods of teaching social studies on academic performance of secondary students in
Akwa Ibom State, Nigeria [Versi elektronik]. British Journal of Arts and Social Sciences, 8, 95-102

Erdogan, Y., Bayram, S., \& Deniz, L. (2008). Factors That Influence Academic Achievement and Attitudes in Web Based Education [Versi Elektronik]. International Journal of Instruction, $1,31-48$

Filippatou, D. \& Kaldi, S. (2010). The effectiveness of Project-based learning on pupils with learning difficulties regarding academic performance, group work and motivation [Versi elektronik]. International Journal of Special Education, 25, 17-26

Gultekin, M. (2005). The Effect of Projectbased learning on Learning outcomes in the 5th Grade Social Studies Course in Primary Education [Versi elektronik]. Educational Science: Theory and Practice, 5(2), 548-556

Han, S., Capraro, R., \& Capraro, M. (2014). How science, technology, engineering, and mathematics (STEM) projectbased learning (PBL) affects high, middle, and low achievers differently: The impact of student factors on achievement. Diambil pada tanggal 15 Mei 2015, dari http://link.springer.com/article/10.100 7/s10763-014-9526-0

Helen. I.N.N. (2013). Effects of guided-inquir and expository teaching methods on senior secondary school students' performances in Biology in Imo State [Versi Elektronik]. Journal of Education Research and Behavioral Sciences, 2(4), 51-57

Hosnan. (2014). Pendekatan saintifik dan kontekstual dalam pembelajaran Abad 21. Jakarta: Ghalia Indonesia

Karaman, S. \& Celik, S. (2008). An exploratory study on the perspectives of prospective computer teachers following Project-based learning [Versi elektronik]. International Journal of Technology Design Education, 18, 203-215 


\section{Jurnal Prima Edukasia, 4 (1), Januari 2016 - 119}

Noviarda Yastika, Haryanto

Kemendikbud. (2013). Panduan teknis pembelajaran tematik terpadu dengan pendekatan saintifik di sekolah dasar. Jakarta: Kemendikbud

Knight, J. (2013). High impact instruction a framework for great teaching. Thousand Oaks CA: Sage

Laur, D. (2013). Authentic learning experiences a real-world approach to projectbased learning. New York: Routledge

Le Hong Sharon Yam, \& Rossini, P. (2010). Implementing a project-based learning approach in an introductory property course. [Versi elektronik]. $16^{\text {th }}$ Pacific Rim Real Estate Society Conference

Martin, J. M. (2009). Elementary science methods: a constructivist approach, fifth edition. Belmont CA: Wadsworth

Mettas, A. C. \& Constantionou, C.C. (2007). The Technology Fair: a Project-based learning approach for enhancing problem solving skills and interest in design and technology education [Versi elektronik]. International Journal of Technology Design Education, 18, 79-100

Moon, J. (2002). The module \& programme development handbook a practical guide to linking levels, learning outcomes \& assessment. London: Kogan

Moore, Kenneth. (2012). Effective instructional strategies. Thousand Oaks CA: Sage

Nitko, A.J., \& Brookhart, S.M. (2011). Educational assessment of students. Boston: Pearson

Oya, R., \& Budiningsih, C. (2014). Peningkatkan motivasi dan hasil belajar Bahasa Indonesia menggunakan model pembelajaran kreatif dan produktif. Jurnal Prima Edukasia, 2(1), 116-126. (Diakses melalui

http://journal.uny.ac.id/index.php/jpe/ article/view/2649 pada hari Selasa, 14 Juli 2015)

Romanov, K. \& Nevgi, A. (2008). Student activity and learning outcomes in a virtual learning environment [Versi elektronik]. Learning Environments

Research, 11, 153-162

Sigler, E.A., \& Saam, J. (2007). Constructivist or expository instructional approaches: Does instruction have an effect on the accuracy of Judgment of Learning (JOL)? [Versi Elektronik]. Journal of the Scholarship of Teaching and Learning, 7, 22-31

Slavin, R.E. (2006). Educational psychology theory and practice. Boston: Pearson

Srinath, A. (2014). Active learning strategies: an illustrative approach to bring out better learning outcomes from science, technology, engineering and mathematics (STEM) students [Versi elektronik]. International Journal of Emerging Technologies in Learning, 9, 21-25

Steven, S. (2015). Learning outcomes in an online vs traditional course [Versi elektronik]. International Journal for the Scholarship of Teaching and Learning, 9, 1-18

Sukmadinata, N.S. (2013). Metode penelitian pendidikan. Bandung: Rosda

Sudjana, N. (2013). Penilaian hasil proses belajar mengajar. Bandung: Rosdakarya

Tseng, K.H., Chang, C.C., Lou, S.J. et al. (2013). Attitudes towards science, technology, engineering and mathematics (STEM) in a Projectbased learning (PjBL) environment [Versi elektronik]. International Journal of Technology Design Education, 23, 87-102

Wahyudi, A., \& Suardiman, S. (2013). Meningkatkan karakter dan hasil belajar IPS menggunakan metode bermain peran pada siswa SD. Jurnal Prima Edukasia, 1(2), 113-123. (Diakses melalui http://journal.uny.ac.id/index.php/jpe/ article/view/2629/2184 pada hari Selasa, 14 Juli 2015)

Westwood, P. (2011). Commonsense methods for children with spesial education need. New York: Routledge. 